\title{
ANALISIS BUNYI, KATA, DAN CITRAAN DALAM PUISI ANAK
}

\author{
Oleh: \\ Itaristanti, M.A.
}

\begin{abstract}
Abstrak
Tulisan ini mendeskripsikan hasil analisis bunyi, kata, dan citraan terhadap beberapa puisi anak. Tujuannya bukan untuk mengkaji secara terpisah-pisah, tetapi mengkaji setiap bagian untuk mendapatkan hubungan yang menyeluruh. Hal ini dilakukan karena bagian-bagian tersebut merupakan unsur yang saling berkaitan dalam bangunan sebuah puisi anak. Dalam aplikasi pengajarannya, pemanfaatan ketiga unsur tersebut dapat merangsang kreativitas anak.
\end{abstract}

Kata kunci: puisi anak, bunyi, kata, dan citraan.

\section{A. Pendahuluan}

Puisi mulai dikenalkan dan diajarkan kepada anak-anak saat mereka duduk di Sekolah Dasar. Namun, pengajarannya tentunya diberikan sesuai dengan tingkat kelasnya. Sebagai contoh, pada saat kelas II anak-anak masih diajari cara membaca dan menyalin puisi anak, mendengarkan pembacaan puisi anak serta praktik mendeklamasikannya dengan ekspresi yang tepat. Pembuatan puisi pada taraf Sekolah Dasar baru diajarkan di kelas V.

Pengajaran puisi dan penulisannya pada anak-anak tentunya harus memperhatikan bunyi, pemilihan kata yang tepat, dan penggunaan citraan walaupun kemudian dimaklumi bahwa bentuk puisi anak biasanya sangat sederhana. Perhatian terhadap unsur-unsur tersebut bukan bermaksud mempersulit cara penulisan puisi pada anak-anak. Akan tetapi, dengan pengajaran penulisan puisi pada anak-anak dengan memperhatikan unsurunsur tersebut justru akan membantu anak untuk menonjolkan ungkapan perasaannya melalui puisi tersebut. Karena hal itulah, penulis tertarik untuk mendeskripsikan penggunaan dan pemanfaatan bunyi, kata, dan citraan pada puisi anak agar pembaca mendapatkan gambaran tentang puisi anak itu 
sendiri. Harapan lebih lanjut, semoga tulisan ini dapat menjadi referensi bagi guru ketika mengajarkan puisi kepada anak-anak usia Sekolah Dasar.

Adapun hal yang ingin diuraikan dalam tulisan ini adalah pemanfaatan bunyi, pemilihan kata (diksi), dan pemanfaatan citraan dalam puisi anak. Tujuannya jelas, yaitu untuk mengetahui dan mendeskripsikan ketiga unsur tersebut serta saling keterkaitan di antara ketiganya dalam membangun suasana dan makna puisi anak.

\section{B. Pembahasan}

\subsection{Pengertian Puisi dan Puisi Anak}

Berdasarkan KBBI, puisi merupakan ragam sastra yang bahasanya terikat oleh irama, matra, rima serta penyusunan larik dan bait (1995: 794). Senada dengan pendapat tersebut, Wirjosoedarmo juga menyatakan bahwa puisi adalah karangan yang terikat oleh banyaknya baris dalam tiap bait, banyaknya kata dalam tiap baris, banyaknya suku kata dalam tiap baris serta adanya rima dan irama (dalam Pradopo, 2005: $5)$.

Berbeda dengan pendapat di atas, Pradopo menyatakan bahwa definisi Wirjosoedarmo tersebut tentunya sudah tidak cocok lagi dengan wujud puisi zaman sekarang (2005: 5). Pradopo kemudian lebih menyetujui pendapat yang dikemukakan oleh Shahnon Ahmad yang telah mengkaji definisi-definisi puisi yang dikemukakan para penyair romantik Inggris, yaitu Samuel Taylor Coleridge, Carlyle, Wordsworth, Auden, Dunton, dan Shelley.

Coleridge menyatakan bahwa puisi adalah kata-kata yang terindah dalam susunan terindah. Carlyle menyatakan bahwa puisi merupakan pemikiran yang bersifat musikal. Wordsworth mempunyai gagasan bahwa puisi adalah pernyataan perasaan yang imajinatif, yaitu perasaan yang direkakan atau diangankan. Auden menyatakan bahwa puisi itu lebih merupakan pernyataan perasaan yang bercampur-baur, sedangkan menurut Dunton, puisi adalah pemikiran manusia secara 
konkret dan artistik dalam bahasa emosional serta berirama. Sementara itu, Shelley mengemukakan bahwa puisi adalah rekaman detik-detik paling indah dalam hidup kita, misalnya yang mengesankan dan mengharukan (Pradopo, 2005: 6).

Shahnon Ahmad kemudian menyatakan bahwa jika pendapatpendapat tersebut dipadukan, didapat unsur-unsur yang menggarisbawahi pengertian puisi (dalam Pradopo, 2005: 7). Unsur yang pertama berkaitan dengan pemikiran, ide, atau emosi. Unsur yang kedua berupa bentuk, sedangkan unsur yang ketiga adalah kesan. Semuanya terungkap dengan media bahasa. Jadi, puisi merupakan rekaman dan interpretasi pengalaman manusia yang digubah dalam wujud yang paling berkesan (Pradopo, 2005: 7).

Berkaitan dengan hal tersebut, ada juga pembagian puisi atas puisi terikat dan puisi bebas. Puisi terikat tentunya senada dengan pengertian yang dinyatakan di dalam KBBI dan pendapat Wirjosoedarmo di atas. Puisi bebas adalah puisi yang tidak terikat oleh rima dan matra, jumlah larik dalam tiap bait, dan jumlah suku kata dalam setiap larik (KBBI, 1995: 794).

Sementara itu, puisi anak dapat dibuat oleh anak-anak. Selain oleh anak-anak, puisi anak juga dapat ditulis oleh orang dewasa yang memiliki kemampuan menulis sastra anak, yaitu karya sastra yang menempatkan sudut pandang anak sebagai pusat penceritaan (Sugihastuti dalam Ampera, 2010: 16). Bentuk puisi anak biasanya sederhana dan arti yang disampaikannya sangat jelas. Sebagai contoh, puisi seorang anak yang ditujukan kepada ibu atau gurunya. Meskipun terlihat sederhana dan ringan, puisi anak tetap harus dihargai karena dapat menambah semangat anak dalam membuat puisi. Dengan demikian, bakat anak dapat terlihat.

\subsection{Bunyi, Kata, dan Citraan}

Bunyi merupakan salah satu unsur yang membentuk puisi. bunyi tersebut dapat menciptakan dan menambah keindahan. Menurut 
Pradopo, bunyi dapat memperdalam ucapan, menimbulkan rasa, dan menimbulkan bayangan angan yang jelas, dan menimbulkan suasana yang khusus (2005: 22). Berkaitan dengan puisi, bunyi dibagi menjadi dua macam, yaitu efoni dan kakofoni. Efeoni merupakan kombinasi bunyi yang merdu dan berirama, sedangkan kakofoni adalah kombinasi bunyi yang tidak merdu.

Bunyi efoni dapat menggambarkan perasaan mesra, kasih sayang, cinta, dan hal-hal lain yang menggembirakan. Berkebalikan dengan efoni, kakofoni dapat memperkuat suasana yang tidak menyenangkan.

Unsur yang membangun puisi setelah bunyi adalah kata. Kata merupakan satuan bahasa yang dapat berdiri sendiri (Kridalaksana, 2011: 110). Pengalaman seseorang dapat digambarkan melalui kata-kata. Kata-kata tersebut kemudian dimanfaatkan dalam pembentukan karya sastra. Dalam hal ini, pengarang harus memperhatikan diksi (pemilihan kata). Kata harus dipilih dengan setepat-tepatnya agar pengalaman seseorang dapat terungkap.

Unsur ketiga yang membangun puisi adalah citraan. Citraan merupakan gambaran angan (Pradopo, 2005:79). Citraan ini berfungsi untuk membuat lebih hidup gambaran yang ada di dalam pikiran. Gambaran-gambaran angan dapat tercipta dari indera penglihatan, pendengaran, perabaan, pengecapan, dan penciuman. Gerakan pun dapat menimbulkan gambaran angan.

\subsection{Analisis Bunyi, Kata, dan Citraan pada Puisi Anak}

Dalam makalah ini, terdapat lima puisi anak. Ketiga aspek yang membangun puisi-puisi anak tersebut kemudian penulis analisis. Berikut uraian mengenai analisis beberapa puisi anak yang dijadikan sampel dalam tulisan ini. 
Anisa Damayanti:

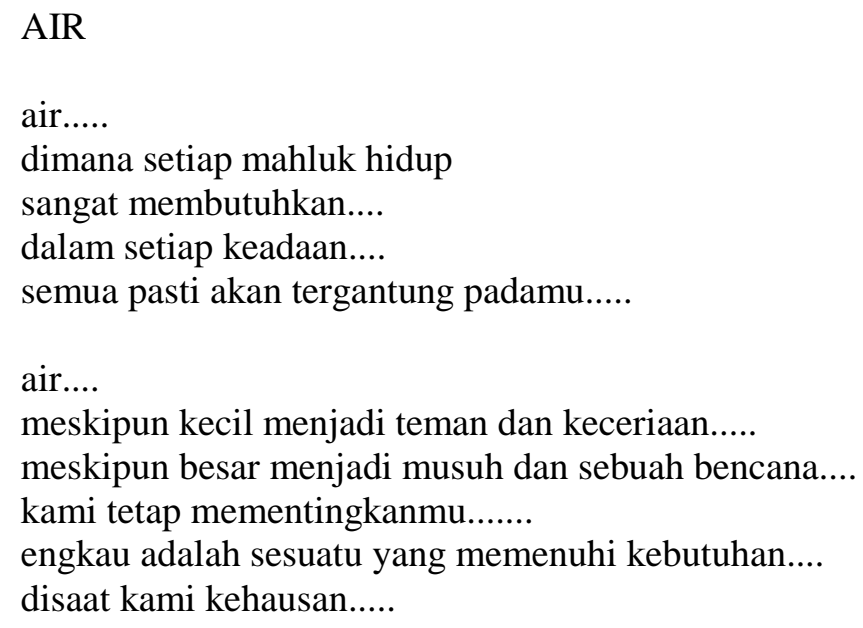

Bunyi yang tampak dominan dalam puisi yang berjudul 'Air' di atas adalah bunyi vokal [a] dan [u], misalnya pada kata makhluk, hidup, musuh, padamu, mementingkanmu, dan sesuatu. Bunyi vokal [a] dan [u] tersebut kemudian menyatu dengan bunyi-bunyi vokal yang lain, seperti bunyi [i] dan [e]. Bunyi vokal [o] tidak tampak dalam puisi tersebut. Sementara itu, bunyi konsonan yang dominan muncul adalah bunyi [n], misalnya pada kata membutuhkan, keadaan, teman, keceriaan, kebutuhan, dan kehausan. Bunyi konsonan [n] tersebut sering muncul pada akhir baris sehingga dapat menambah keindahan bunyi dalam puisi.

Berkaitan dengan kata, puisi di atas dibangun oleh kata-kata yang yang bersifat denotatif. Denotasi berarti makna kata atau kelompok kata yang didasarkan atas penunjukan yang lugas (KBBI, 1995: 223). Hal ini terkait dengan penguasaan bahasa pada anak-anak yang memang masih terbatas. Mereka belum begitu mengerti tentang kata-kata kiasan atau konotasi sehingga mereka lebih banyak menggunakan kata-kata yang sifatnya lugas. Namun begitu, anak-anak juga mulai belajar menggunakan kata kiasan tersebut serta memilih kata yang tepat untuk memperdalam makna puisi.

Dalam puisi di atas, pengarang ingin menyampaikan pentingnya air dalam kehidupan manusia. Hal tersebut dapat dilihat pada pernyataanpernyataan di setiap barisnya. Baris kedua dalam bait kedua berbunyi 
"meskipun kecil menjadi teman dan keceriaan", sedangkan baris ketiga berbunyi "meskipun besar menjadi musuh dan sebuah bencana". Dalam pernyataan tersebut terdapat kata teman dan musuh. Penggunaan kata teman menyatakan bahwa ketika air itu berada dalam kapasitas yang cukup maka ia akan memenuhi kebutuhan manusia. Sebaliknya, apabila kapasitas air melebihi batas yang sewajarnya maka air dapat menjadi bencana. Bencana dalam puisi tersebut diibaratkan sebagai musuh. Sebenarnya, pengarang ingin mengatakan banjir. Akan tetapi, agar memperdalam makna puisi, pengarang kemudian memilih menyatakan banjir sebagai musuh.

Citraan yang terlihat dalam puisi tersebut adalah citraan penglihatan dan pencecapan. Hal tersebut tampak pada penggunaan kata keceriaan dan kehausan. Kata keceriaan menunjukkan wajah yang terlihat gembira, sedangkan kata kehausan menunjukkan keringnya tenggorokkan dan ingin minum. Hal tersebut berkaitan dengan indera pencecapan. Kedua citraan tersebut dimanfaatkan oleh pengarang untuk memberikan kesan pada puisi yang ia buat. Kesan tersebut kemudian dapat dibayangkan dan dirasakan oleh pembaca.

Contoh puisi yang kedua berjudul "Liburan Telah Tiba" karya Damar. Dalam puisi di bawah ini terdiri dari tiga bait. Bait pertama terdiri dari lima baris, sedangkan bait kedua dan ketiga terdiri dari empat baris.

Damar:

\section{LIBURAN TELAH TIBA}

Pagi yang cerah

$\mathrm{Ku}$ bergegas menuju sekolah

Suara gemuruh

Lonceng sekolah

$\mathrm{Ku}$ nikmati masa-masa yang indah

Hangat sapa bersama teman

Memupuk tawa bersama kawan 
Menuntut ilmu ku kerahkan

Demi meraih masa depan

Kemampuan otak terkuras lemah

Terdiam suntuk merasa lelah

Menanti hari-hari yang indah

Dan ku sambut libur sekolah

Pada bait pertama, bunyi konsonan [h] selalu muncul di setiap akhir baris, yaitu pada kata cerah, sekolah, gemuruh, dan indah. Pada bait kedua, di setiap akhir baris selalu berakhir dengan bunyi konsonan [n], yaitu pada kata teman, kawan, kerahkan, dan depan. Sementara itu, bunyi konsonan [h] muncul kembali pada bait ketiga, yaitu pada kata lemah, lelah, indah, dan sekolah. Bunyi-bunyi konsonan yang dominan tersebut kemudian berkombinasi dengan bunyi-bunyi vokal sehingga menciptakan bunyi yang selaras dan indah. Permainan bunyi sangat terlihat dalam puisi anak yang kedua ini. Citraan yang tampak pada puisi tersebut sangat mendukung arti atau kesan yang ingin diungkapkan oleh pengarang.

Citraan tersebut berupa citraan penglihatan, gerakan, pendengaran, dan perabaan. Citraan penglihatan dan gerakan dapat dipahami dari ungkapan pengarang pada kalimat "pagi yang cerah, ku bergegas menuju sekolah". Gambaran tentang pagi yang cerah kemudian dapat ditangkap dan dibayangkan oleh pembaca. Pembaca juga dapat membayangkan langkah si aku dalam puisi tersebut yang bergegas berangkat ke sekolah. Citraan pendengaran terasa dalam baris yang berbunyi "suara gemuruh lonceng sekolah". Sementara itu, citraan perabaan terasa pada kalimat "hangat sapa bersama teman". Pemilihan kata hangat digunakan untuk menunjukkan rasa yang akrab kepada teman-teman. Pemanfaatan citraan-citraan tersebut dapat mendukung pengungkapan perasaan dan makna yang ingin disampaikan pengarang, yaitu suka dan duka masa sekolah dan penantiannya terhadap liburan sekolah. 
Puisi anak biasanya bercerita tentang keinginan atau pun hal-hal yang ditemui atau dialami pengarangnya. Jika dalam puisi yang kedua di atas pengarang menceritakan pengalamannya saat masa-masa sekolah, contoh puisi yang ketiga berikut menceritakan tentang sosok gurunya.

\section{Gusti Neka Putri:}

\section{GURU TERCINTA}

Sapa hangat penuh senyum semangat Kau tebarkan ilmu yang bermanfaat Demi anak didik kau berikan nasehat Jasa mulia goncangkan akhirat

Nyanyian mentari terangi alam

Terangi mimpi bagai mentari

Masa depan bangsa telah kau perjuangkan

Korbankan waktu demi masa depan

Terimakasih aku ucapkan

Guru tercinta panutan alam

Jasa besarmu tak terlupakan

$\mathrm{Ku}$ kirimkan puisi untukmu pahlawan

Melalui puisi di atas, pengarang ingin menyampaikan rasa terimakasih kepada gurunya. Sosok guru tersebut kemudian diceritakan sebagai sosok yang ramah, bersemangat, dan gigih memperjuangkan masa depan bangsa melalui pengajaran. Sifat yang ramah tersebut tercermin dari pemilihan kata sapa, hangat, dan penuh senyum pada baris pertama bait pertama. Citraan pendengaran kemudian dapat dirasakan melalui kata sapa. Citraan penglihatan tampak pada frase penuh senyum. Kata hangat digunakan untuk lebih menonjolkan sifat ramah sang guru. Selain melalui kata sapa, citraan pendengaran juga tercermin melalui kata nyanyian pada baris pertama bait kedua. Citraan penglihatan juga tampak melalui kata terangi pada baris yang berbunyi "terangi mimpi bagai mentari”.

Bunyi yang dominan muncul dalam puisi di atas adalah bunyi konsonan [t] dan bunyi [n]. Bunyi [t] muncul pada kata semangat, 
bermanfaat, nasehat, dan akhirat dalam bait pertama. Bunyi [n] muncul dalam kata perjuangkan, depan, ucapkan, terlupakan, dan pahlawan. Bunyi tersebut sering muncul di akhir baris sehingga menciptakan bunyi yang indah dan bersajak. Bunyi-bunyi tersebut kemudian berpadu dengan bunyi-bunyi vokal yang dapat menggambarkan suasana yang menyenangkan dan penuh semangat.

Puisi yang keempat berjudul "Sahabat" karya Ferdinaen Saragih. Dalam puisi ini, pengarang menceritakan hubungan dengan sahabatnya. Puisi ini terdiri dari tiga bait.

Ferdinaen Saragih:

\section{SAHABAT}

Kita saling berlari

Menuju sekolah

Bersama bermain

Riang di halaman

Tak jarang kita

Berbeda pendapat

Lalu kita berkelahi kecil

Dan saling diam

Tapi itu tak akan lama

Karena kita sahabat sejati

Yang selamanya

Akan tetap menjadi sahabat

Pengarang menyebutkan bahwa ia pergi ke sekolah dan bermain bersama sahabatnya. Kadang-kadang, mereka saling berkelahi karena berbeda pendapat, tetapi tidak berlangsung lama karena mereka adalah sahabat sejati.

Bunyi konsonan tidak ada yang tampak dominan dalam puisi tersebut. Sementara itu, bunyi vokal [a] sering muncul. Bunyi konsonan dan vokal tersebut kemudian saling berkombinasi.

Melalui kata diam dapat dirasakan bahwa citraan yang muncul adalah citraan pendengaran. Kata diam berarti tidak bersuara (KBBI, 1995: 230). Pembaca seolah-olah tidak mendengar apa pun. Semuanya 
sunyi senyap. Kata diam tersebut dipilih oleh pengarang untuk menggambarkan dampak konflik setelah dirinya berkelahi kecil dengan sahabatnya, mereka tidak saling bercakap-cakap. Pemilihan kata yang tampak dalam puisi tersebut adalah kata-kata yang lugas dan mudah dimengerti.

Puisi yang kelima juga ditulis oleh Ferdinaen Saragih. Puisi berikut berjudul "Polusi Udara". Puisi berikut terdiri dari empat bait. Setiap bait terdiri dari tiga baris.

Ferdinaen Saragih:

\section{POLUSI UDARA}

Belum lagi terdengar kicauan burung pagi Udara kota telah berubah menjadi hitam Membuat sesak untuk bernafas

Kotaku tidak seperti dulu lagi Udara telah tercemar di sini Polusi telah bertebaran di seluruh penjuru

Dulu masih banyak pohon di sini Tumbuh mengikuti alur jalan Tapi, kini bisa dihitung dengan jari

Asap-asap kendaraan Pabrik-pabrik, semakin hari kian bringas Memenuhi udara di kota ini

Bunyi konsonan yang sering muncul antara lain bunyi $[\mathrm{r}],[\mathrm{t}],[\mathrm{p}]$, dan [n]. Sementara itu, bunyi vokal yang sering muncul adalah bunyi [a], [e], [u], dan [i]. Bunyi [o] jarang dipakai. Bunyi-bunyi tersebut kemudian berpadu dengan bunyi yang lain. Penggunaan bunyi dalam puisi di atas kurang teratur. Ketidakteraturan bunyi tersebut mendukung suasana yang dibangun oleh pengarangnya.

Suasana yang dibangun dalam puisi di atas adalah suasana yang tidak menyenangkan. Pengarang mengungkapkan keadaan di mana udara di kota telah dipenuhi oleh asap kendaraan dan asap pabrik. Asap- 
asap tersebut membuat manusia susah bernafas. Bahkan, burung pun sudah tidak terdengar kicauannya lagi. Kemungkinan mereka telah mati.

Suasana tersebut tentunya dapat dirasakan oleh pembaca karena adanya citraan atau gambaran angan yang digunakan oleh pengarangnya. Pada bait pertama terdapat kalimat yang berbunyi "Belum lagi terdengar kicauan burung pagi”. Kalimat tersebut memanfaatkan citraan pendengaran. Kalimat "Udara kota telah berubah menjadi hitam" pada baris kedua memanfaatkan citraan penglihatan. Begitu juga dengan bait ketiga baris pertama. Pembaca dituntun untuk membayangkan bahwa dahulu masih banyak pohon di pinggir jalan, tetapi sekarang telah banyak berkurang dan hanya dalam hitungan jari saja. Frase hitungan jari di situ dimanfaatkan pengarang untuk menyatakan jumlah yang sedikit. Akan tetapi, untuk lebih menghidupkan puisi tersebut, dipilihlah kata hitungan dan jari yang kemudian membentuk frase hitungan jari yang mempunyai satu makna. Kesemua pencitraan dan pemilihan kata tersebut membangun gambaran angan pada para pembacanya.

\section{SIMPULAN DAN SARAN}

Dari analisis beberapa contoh puisi anak yang dijadikan sampel dalam makalah ini, dapat diambil beberapa simpulan. Simpulan tersebut dapat penulis uraikan sebagai berikut.

Puisi anak dibangun oleh beberapa unsur, yaitu unsur bunyi, kata, dan citraan. Bunyi-bunyi yang dikombinasikan dalam puisi anak tidak selamanya bunyi yang teratur. Bunyi yang tidak teratur dapat dimanfaatkan untuk membangun suasana yang tidak menyenangkan. Sementara itu, keteraturan bunyi dapat menimbulkan irama yang indah. Irama yang indah dapat menggambarkan suasana yang syahdu, haru, gembira, atau pun suasana yang sedih yang mendalam.

Dalam pembuatan puisi anak, pengarang juga dapat memilih kata yang paling tepat untuk memperdalam makna puisi. Pengarang puisi anak yang merupakan orang dewasa tentunya dalam memilih kata harus 
memperhatikan tingkat kemampuan anak-anak dalam memahami kosakata. Sebagian besar, kata-kata yang ada dalam puisi anak adalah kata-kata yang mudah dipahami, bermakana lugas/denotasi, dan sederhana.

Unsur ketiga yang dapat membangun puisi anak adalah citraan. Citraan digunakan pengarang untuk membangun gambaran angan atau pikiran pembacanya. Dengan adanya gambaran-gambaran tersebut, pembaca dapat membayangkan atau merasakan hal yang diungkapkan pengarang dalam puisi anak tersebut. Citraan dapat merangsang dan mengasah daya imajinasi anak. Imajinasi tersebut kemudian dapat membuat anak lebih kreatif dalam berkarya. 


\section{DAFTAR PUSTAKA}

Ampera, Taufik. 2010. Pengajaran Sastra: Teknik Mengajar Sastra Anak Berbasis Aktivitas. Bandung: Widya Padjajaran.

Kridalaksana, Harimurti. 2011. Kamus Linguistik. Jakarta: Gramedia Pustaka Utama.

Pradopo, Rachmat Djoko. 2005. Pengkajian Puisi. Yogyakarta: Gadjah Mada University Press.

Tim Penyusun Kamus. 1995. Kamus Besar Bahasa Indonesia. Jakarta: Balai Pustaka.

Sumber internet diunduh pada Selasa, 19 November 2013, pukul 20.05 WIB:

www.huddyp.blogspot.com > Puisi

http://khezo.com/puisi-anak/

www.problogger.web.id/2013/.../kumpulan-puisi-anak-sekolah-2013.

http://www.sigodangpos.com/2011/09/puisi-anak-sahabat.html 